\title{
Using Plastic Mulching Improves Greenhouse-Grown Pakchoi (Brassica rapa subsp. chinensis) Growth and Water Use Efficiency under Irrigation Scheduling Based on Soil Water Content
}

\author{
Yue Xie ${ }^{1}$, Shenglin Wang ${ }^{1}$, Chen Luo ${ }^{1}$, Mengyao Sun ${ }^{2}$, Yixin Wang ${ }^{1}$, Jingjing Yang ${ }^{1}$ and \\ Qian Wang ${ }^{1, *(D)}$ \\ 1 Department of Vegetables, Beijing Key Laboratory of Growth and Developmental Regulation for Protected \\ Vegetable Crops, China Agricultural University, Beijing 100193, China; yue.xie@cau.edu.cn (Y.X.); \\ b20173170776@cau.edu.cn (S.W.); chenluo@cau.edu.cn (C.L.); s20183172273@cau.edu.cn (Y.W.); \\ yangjingjing@nercv.org (J.Y.) \\ 2 Beijing Agricultural Machinery Experiment Appraisal Extension Station, Beijing 100079, China; \\ sun_mengyao2020@outlook.com \\ * Correspondence: wangq@cau.edu.cn
}

Received: 31 July 2020; Accepted: 24 August 2020; Published: 26 August 2020

\begin{abstract}
Scarce water resources limit protected vegetable production in North China. Implementing efficient water-saving techniques is crucial for maintaining protected vegetable production and sustainability. A two-growing season field experiment was conducted in a glass greenhouse to explore the effects of water-saving techniques with irrigation scheduling based on soil water content on the growth and quality of pakchoi and the fate of irrigation water. Three water-saving techniques were investigated: micro-irrigation (M-0), furrow irrigation with plastic mulch (F-P), and micro-irrigation with plastic mulch (M-P) compared to furrow irrigation (F-0). F-P and M-P treatments enhanced pakchoi growth and primarily increased the total root length of the root system $(0-0.2 \mathrm{~m})$ compared to F-0. The two treatments further induced an improvement of pakchoi quality. Compared to M-0, F-P and M-P treatments showed better performance in reducing evaporation by $57-70 \%$ and proportion of evaporation in evapotranspiration, and consequently exhibited more pronounced effects on water saving. Irrigation water use efficiency (IWUE) was improved in F-P by $50 \%$ in both seasons and was improved in M-P by 84 and 95\% in spring season and autumn season, respectively. Combining irrigation scheduling based on soil water content with plastic mulch is a feasible way to improve IWUE in protected vegetable production by reducing water consumption and enhancing crop growth.
\end{abstract}

Keywords: irrigation water use efficiency; micro-irrigation; plastic mulch; pakchoi; root morphology; vegetable quality

\section{Introduction}

Protected vegetable cultivation releases vegetable production from the constraints of climatic conditions, allowing year-round production. A protected vegetable production system is covered by glass or plastic materials, creating a closed or semi-closed environment. Such an environment determines that the production inevitably depends on irrigation. As protected vegetable production and the demand for vegetable consumption are increasing [1], the water consumption in such production may put pressure on water resources (i.e., groundwater), which are scarce in North China [2]. Additionally, irrational irrigation by growers can exacerbate the problem of water scarcity [3]. Traditional surface irrigation methods (such as furrow irrigation) with low irrigation water use 
efficiency (IWUE) are widely applied in over 90\% of irrigation areas [4] and are commonly seen in Chinese protected vegetable production where many farmers lack knowledge and are not willing to put in the extra work for advanced irrigation techniques. To alleviate the overexploitation of groundwater and achieve sustainable agriculture, it is important to develop and implement water-saving techniques for protected vegetable production.

Water-saving techniques, compared to furrow irrigation, can reduce water consumption, improve crop yields and consequently improve IWUE to various extents depending on the crop species and agronomic conditions. For instance, irrigation scheduling based on soil water content can save water, improve the yield and quality of vegetables, and increase IWUE [5,6]. Drip and micro-sprinkling irrigation have been developed to improve water use efficiency [7]. Drip irrigation reduces water consumption by $6-30 \%$ and improves the yield of cotton (Gossypium hirsutum L.) by $38 \%$ compared to furrow irrigation, leading to high IWUE [8]. Micro-sprinkling irrigation with similar water supply rates as furrow irrigation improves the growth and yield of winter wheat (Triticum aestivum L.), thereby increasing IWUE [9]. Moreover, the use of plastic mulch has been reported to reduce water consumption and evaporation and increase yield [10-12]. However, some water-saving techniques may induce water stress and subsequently change the development of roots. Changes in root development further influence water and nutrient uptake and consequently plant growth [13,14]. On the other hand, water stress induced by water-saving techniques affects the quality of vegetables (such as soluble solids and vitamin C), particularly fruity vegetables $[15,16]$, due to the osmotic potential regulation or stimulation of antioxidant activity. Moreover, the use of plastic mulch, particularly combined with drip irrigation, improves the micro-environment and nutrient uptake, and consequently vegetable quality $[10,17]$.

Pakchoi (Brassica rapa subsp. chinensis), which originated in China, is a short-season vegetable prevalent in China and can be grown in the northern and southern parts of the country. To date, there is a lack of studies revealing the water use and response of greenhouse-grown pakchoi production to water-saving techniques. In order to fill the gap, a two-growing season experiment was conducted in a glass greenhouse to investigate the performance of water-saving techniques, micro-irrigation and plastic mulch, in water savings in greenhouse-grown pakchoi. These water-saving techniques were combined with irrigation scheduling based on soil water content. The performance was evaluated by measuring the pakchoi growth and quality and the fate of irrigation water. We hypothesized that (1) micro-irrigation and the use of plastic mulch would improve IWUE by enhancing crop growth and quality and reducing the water consumption; and (2) the combined use of plastic mulch and micro-irrigation would have the best performance in improving IWUE.

\section{Materials and Methods}

\subsection{Experimental Sites and Design}

The experiment was carried out during spring and autumn in 2016, in a greenhouse located at the experiment station of China Agricultural University, Beijing, China $\left(39^{\circ} 54^{\prime} \mathrm{N}, 116^{\circ} 23^{\prime} \mathrm{E}\right)$. The soil had a bulk density of $1.00 \mathrm{~g} \mathrm{~cm}^{-3}$ and field capacity of $38.97 \%$ after tillage. The organic matter content in the soil was $2.28 \%$ before the experiment started. Total $\mathrm{N}$ and available $\mathrm{N}$ content was $1.55 \mathrm{~g} \mathrm{~kg}^{-1}$ and $198.47 \mathrm{mg} \mathrm{kg}^{-1}$ and Olsen-P and K content was 107.72 and $163.33 \mathrm{mg} \mathrm{kg}^{-1}$, respectively.

A completely random design was used to investigate three water-saving techniques: micro-irrigation (M-0), furrow irrigation with plastic mulch (F-P), and micro-irrigation with plastic mulch (M-P). These techniques were compared to the traditional furrow irrigation (F-0). Each treatment had three replicated plots. The plot size was $3.6 \mathrm{~m}^{2}(3.6 \mathrm{~m} \times 1 \mathrm{~m})$. Four rows of pakchoi were planted in one plot with a row distance of $0.25 \mathrm{~m}$. The micro-irrigation system was constituted by $28.6 \mathrm{~mm}$ diameter pressured hoses made of black polyethylene. The hoses were attached to a 50-mm diameter main pipe (polyethylene) with a distance of $1 \mathrm{~m}$. Five holes with a diameter of $0.1 \mathrm{~mm}$ were punched in every other $10 \mathrm{~cm}$ of the hoses for water outlet. The five holes were punched with a distance of $2.5 \mathrm{~cm}$ 
between two adjacent holes. One hose with a length of $3.5 \mathrm{~m}$ was arranged in the middle of one plot. The side of the hose with holes was set to face downward, to ensure that the water directly went down into the soil. In the treatments with furrow irrigation (F-0 and F-P), one $3.5 \mathrm{~m}$ hose without holes was arranged straightly in the middle of one plot. Thus, the water outlet of the hose was close to the short side of the plot. White polyethylene plastic film was used to mulch the soil in F-P and M-P treatments after pakchoi was sown. Holes with $10 \mathrm{~cm}$ diameter were made on the white polyethylene plastic mulch by scissors for sowing pakchoi and pakchoi growth. These holes were with a row distance of $0.25 \mathrm{~m}$ and a $0.2 \mathrm{~m}$ distance between two holes interrow. Adjacent plots were divided with a piece of plastic film (polyethylene, without holes) to a soil depth of $0.5 \mathrm{~m}$ in order to avoid water runoff between plots.

The soil water content at $0.15 \mathrm{~m}$ soil depth was monitored by using digital tensiometers (STEP Systems, GmbH, Nürnberg, Germany). One tensiometer was set in one plot and installed $0.25 \mathrm{~m}$ and $1.8 \mathrm{~m}$ away from the long and short side of the plot, respectively. Thus, the tensiometer was $0.25 \mathrm{~m}$ away from the hose and between the first two rows of pakchoi. The relationship between soil water potential and soil relative water content was the same as reported by Chen et al. [10]. Irrigation was set up to start when the field capacity was below $60 \%$. The irrigation amount each time was set as the difference in water amount between 60 and $80 \%$ of field capacity. The irrigation amount was calculated by using Formula (1) [18] and the irrigation amounts were 233.85 and $219 \mathrm{~m}^{3} \mathrm{ha}^{-1}$ in spring and autumn, respectively.

$$
\text { Irrigation amount }=\mathrm{B} \times \mathrm{p} \times \mathrm{D} \times \theta_{\mathrm{f}} \times \mathrm{s} \times\left(\mathrm{q}_{1}-\mathrm{q}_{2}\right) \times \eta
$$

Here $\mathrm{B}$ is the soil bulk density $\left(\mathrm{g} \mathrm{cm}^{-3}\right)$ before the experiment; $\mathrm{p}$ is the soil wetting ratio, taken as $100 \%$; $\mathrm{D}$ is the soil layer, taken as $0.3 \mathrm{~m} ; \theta_{\mathrm{f}}$ is the field capacity $(\%) ; \mathrm{q}_{1}$ and $\mathrm{q}_{2}$ represent the soil water content expressed as \% of field capacity, and were 80 and $60 \%$; $\mathrm{s}$ is the soil area, taken as $3.6 \mathrm{~m}^{2}$; and $\eta$ is the water use coefficiency, which is 1 .

The pakchoi cultivars Chunyou No. 5 and Xialv No. 2 were selected for spring and autumn in 2016 , respectively. Flat bedding cultivation was applied in the experiment with a bed size of $3.6 \mathrm{~m}^{2}$ $(3.6 \mathrm{~m} \times 1 \mathrm{~m})$, meaning one bed per plot. On 13 March and 7 September 2016, pakchoi seeds were sown with a row distance of $0.25 \mathrm{~m}$ by hand in the treatments without plastic mulch (F-0 and M-0), while in F-P and M-P treatments, pakchoi seeds were sown in the soil under each hole of white plastic mulch. There were four rows of pakchoi (a row distance of $0.25 \mathrm{~m}$ ) in each bed/plot. On the same days of sowing, 156 and $219 \mathrm{~m}^{3} \mathrm{ha}^{-1}$ irrigation water was given by the corresponding irrigation method in each treatment in spring and autumn, respectively, for better soil contact with seeds stimulating seeds germination and plant establishment. In the first 2 weeks after sowing, seedlings were thinned twice by hand to keep the plant distance at $0.2 \mathrm{~m}$ in F-0 and M-0 treatments, while in F-P and M-P treatments, seedlings coming out from each hole of plastic mulch were thinned to one plant per hole. Hence, the plant density was 200,000 plants ha ${ }^{-1}$ in all treatments. Basal fertilizer was applied before bedding in the forms of composted chicken manure (total content of $\mathrm{N}, \mathrm{P}$, and $\mathrm{K}$ was more than $4 \%$ and organic matter content was more than $30 \%)$ and synthetic fertilizer $\left(\mathrm{N}: \mathrm{P}_{2} \mathrm{O}_{5}: \mathrm{K}_{2} \mathrm{O}=15: 10: 15\right)$ at rates of $67,500 \mathrm{~kg} \mathrm{ha}^{-1}$ and $1950 \mathrm{~kg} \mathrm{ha}^{-1}$, respectively. The mean daily air temperature during the experimental period in the glass greenhouse was monitored by Greenhouse Baby (Xinyuan Company, Beijing, China) and is shown in Figure 1. 


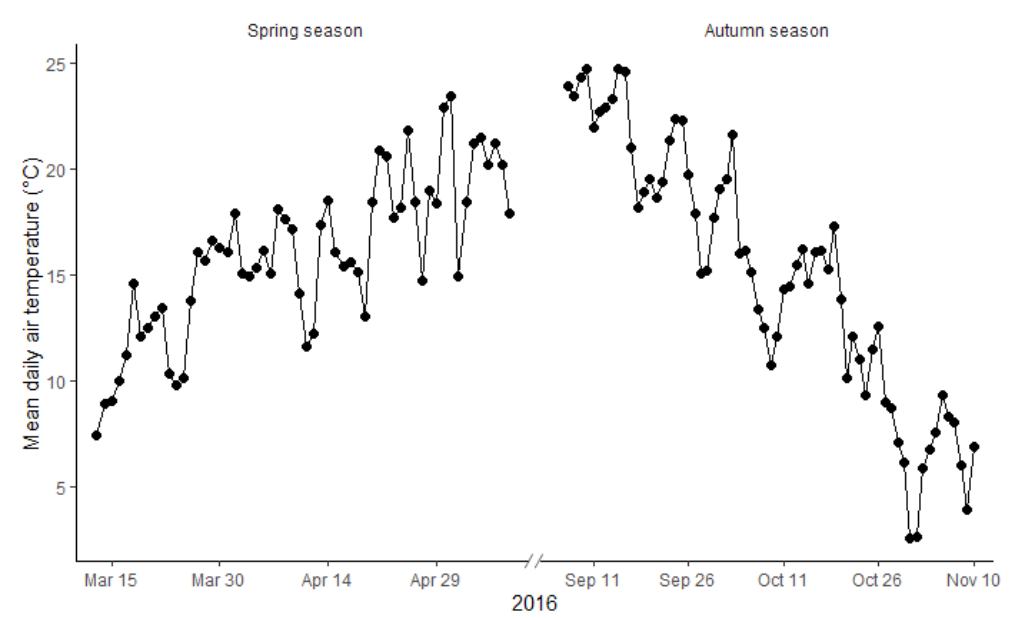

Figure 1. The mean daily air temperature during the two growing seasons.

\subsection{Plant and Soil Samplings}

Pakchoi was harvested on 9 May and 10 November 2016 (two rows of pakchoi $\times 1 \mathrm{~m}$ per plot). The second and third rows were chosen to avoid edge effect. Whole plants were harvested by excavating the soil to a depth of $0.2 \mathrm{~m}$ using a shovel [19]. The aboveground and belowground parts were separated by a knife. The roots were rinsed with tap water to remove soil and dirt. Then, the root systems were divided into top $0.1 \mathrm{~m}$ and roots in $0.1-0.2 \mathrm{~m}$ and stored at $-4{ }^{\circ} \mathrm{C}$ for future analysis. On the same days, soil in the top $0.3 \mathrm{~m}$ soil layer was collected by the soil auger method, for which five spots in an S-shape were selected in each plot [20].

\subsection{Plant and Soil Analysis}

The aboveground and belowground fresh weights were determined. Since no senescence of pakchoi happened at harvest, the yield was measured as the total aboveground fresh weight in the sampled plot without removing any leaves. The total leaf area of each plant $\left(\mathrm{cm}^{2}\right.$ plant $\left.^{-1}\right)$ was scanned by using an Epson Perfection V800 photo scanner and analyzed by WinRHIZO (LC4800-II LA2400, Regent Instruments, Quebec, QC, Canada). The SPAD value of pakchoi was measured on three full expanded leaves by using a SPAD meter (SPAD-502, Minolta Camera Co., Osaka, Japan). The dry biomass of pakchoi was measured after oven-drying at a temperature of $80^{\circ} \mathrm{C}$ to a constant weight. The water content was calculated as the ratio of difference between fresh and dry weight to fresh weight. The content of soluble sugar was measured in fresh pakchoi material by anthrone colorimetry [21]. The vitamin C content was measured by the 2,6-dichloroindophenol titrimetric method [22]. The content of $\mathrm{N}$ and $\mathrm{P}$ in pakchoi was measured with the combustion method according to VDLUFA [23]. The sum of cellulose, hemicellulose and lignin was referred to neutral detergent fiber (NDF). The content of hemicellulose was the content difference between NDF and acid detergent fiber (ADF). NDF and ADF were measured by using a semiautomatic fiber analyzer (ANKOM A200i, ANKOM Technology, Macedon, NY, USA). Before root morphology analysis, the roots were thawed at room temperature. Roots were placed on a transparent plastic plate and scanned (Epson Perfection V800). The root length per plant $\left(\mathrm{cm}\right.$ plant $\left.{ }^{-1}\right)$ was obtained by analyzing the pictures with WinRhizo software (LC4800-II LA2400, Regent Instruments, Quebec, QC, Canada).

The content of $\mathrm{N}$, available $\mathrm{P}$, and available $\mathrm{K}$ in soil was measured with the method according to VDLUFA [23]. Soil EC value $\left(\mu \mathrm{S} \mathrm{cm}^{-1}\right)$ was measured at a 1:5 ratio of soil to distilled water suspension by using a conductivity meter (DDS-307, INESA Scientific Instrument Co., Ltd., Shanghai, China). 


\subsection{Evaporation Measurements}

Evaporation during the two growing seasons was measured by using a micro-evaporator, which was a 100-mm-high PVC tube with an outer diameter of $100 \mathrm{~mm}$ and inner diameter of $90 \mathrm{~mm}$, covered with nylon mesh at the bottom for water and gas exchange. One micro-evaporator was installed in one plot before the plastic mulch was applied. After bedding and before sowing, soil from the plots was collected and packed to micro-evaporators to a bulk density of $1.00 \mathrm{~g} \mathrm{~cm}^{-3}$, the same as the bulk density after tillage. The micro-evaporator was directly installed $0.1 \mathrm{~m}$ away from tensiometer and $0.25 \mathrm{~m}$ away from the hose by digging a hole to fit the PVC tube. The PVC tubes were weighed daily at 16:00 and evaporation was recorded as weight loss between two consecutive days. In F-P and M-P treatments, a hole with 100-mm diameter was made in the plastic film right above the PVC tube and covered with a small piece of plastic film affixed by Scotch tape. The small piece of plastic film was removed for each measurement, so that the PVC tube could be taken out with minimal disturbance to the plastic mulch.

\subsection{Calculation and Data Analysis}

Water use in this experiment was evaluated by irrigation water use efficiency (IWUE) and water partitioning into the soil and plants. IWUE was calculated using Formula (2):

$$
\text { IWUE }=\text { yield } / \text { total irrigation amount }
$$

Since the irrigation amount given was only $20 \%$ of field capacity of water, it was assumed that neither water runoff on the soil surface nor leaching happened during the growing seasons. Therefore, the transpiration of pakchoi during each growing season was calculated using Formula (3):

$$
\text { Transpiration }=\text { Irrigation }-\Delta W-\text { Evaporation }
$$

where irrigation is the total amount given in each growing season; $\Delta W$ is the difference in soil water contents at the start and end of the experiment; and evaporation represents the sum of daily evaporation.

A general linear model procedure ( $R$ software version 3.51) was used for analysis of variance (F-test), to test the effects of water management techniques on pakchoi growth, root morphology, quality, nutrient content, soil EC values, and water use. The data from two growing seasons were analyzed separately. The Shapiro-Wilk test was used to check normality. Data were transformed by the function $y=x^{1 / 2}$ or $y=\log (x)$ to obtain the homogeneity of variance. Multiple comparisons were conducted by using Tukey's test.

\section{Results}

\subsection{Pakchoi Growth and Yield}

The yield of pakchoi in M-P was higher than that in F-0 and M-0 in both growing seasons and higher than that in F-P in autumn season $(p<0.05)$. Compared to F-0, M-P increased the yield by $40.1 \%$ in spring season and $63.6 \%$ in autumn season, respectively. Similarly, the aboveground dry biomass in $\mathrm{M}-\mathrm{P}$ was higher than that in $\mathrm{F}-0$ and $\mathrm{M}-0$ in both growing seasons and higher than that in F-P in autumn season $(p<0.05)$. However, the belowground dry biomass was only influenced by treatments in autumn season, when it was higher in M-P than in F-0 and M-0 $(p<0.05)$. The sum of aboveground and belowground dry biomass accumulation in M-P and F-P was increased by 35.3 and $33.4 \%$, respectively, in spring season and by 64.2 and 30.0\%, respectively, in autumn season (Table 1). 
Table 1. The effects of water management techniques on pakchoi yield, dry biomass accumulation, and irrigation water use efficiency (IWUE) in spring and autumn seasons.

\begin{tabular}{|c|c|c|c|c|c|}
\hline \multirow[t]{3}{*}{$\begin{array}{l}\text { Growing } \\
\text { Seasons }\end{array}$} & \multirow[t]{3}{*}{ Treatments } & \multirow{3}{*}{$\begin{array}{c}\text { Yield } \\
\left(\mathrm{kg} \mathrm{m}^{-2}\right)\end{array}$} & \multicolumn{2}{|c|}{ Dry Biomass } & \multirow{3}{*}{$\begin{array}{c}\text { IWUE } \\
\left(\mathrm{kg} \mathrm{m}^{-3}\right)\end{array}$} \\
\hline & & & Aboveground & Belowground & \\
\hline & & & \multicolumn{2}{|c|}{$\left(\mathrm{g} \mathrm{m}^{-2}\right)$} & \\
\hline \multirow{4}{*}{ Spring } & F-0 & $5.21 \mathrm{~b}$ & $191 \mathrm{~b}$ & $12 \mathrm{a}$ & $17.59 \mathrm{c}$ \\
\hline & M-0 & $5.50 \mathrm{~b}$ & $194 \mathrm{~b}$ & $12 \mathrm{a}$ & $20.18 c$ \\
\hline & F-P & $6.56 \mathrm{ab}$ & $258 \mathrm{a}$ & $13 \mathrm{a}$ & $26.30 \mathrm{~b}$ \\
\hline & M-P & $7.30 \mathrm{a}$ & $259 a$ & $16 \mathrm{a}$ & $32.31 \mathrm{a}$ \\
\hline \multirow{4}{*}{ Autumn } & F-0 & $4.21 \mathrm{c}$ & $188 \mathrm{c}$ & $16 \mathrm{~b}$ & $21.81 \mathrm{c}$ \\
\hline & M-0 & $5.51 \mathrm{~b}$ & $221 b$ & $17 \mathrm{~b}$ & $27.94 \mathrm{c}$ \\
\hline & F-P & $6.09 \mathrm{~b}$ & $244 \mathrm{~b}$ & $21 \mathrm{ab}$ & $32.82 \mathrm{~b}$ \\
\hline & M-P & $6.86 \mathrm{a}$ & $309 a$ & $26 \mathrm{a}$ & $42.60 \mathrm{a}$ \\
\hline
\end{tabular}

Notes: F-0, M-0, F-P, and M-P were abbreviations for furrow irrigation, micro-irrigation, furrow irrigation with plastic mulch and micro-irrigation with plastic mulch. The different lower-case letters indicate the significant difference among water management techniques in each season at $p<0.05(n=3)$.

The roots in the top $0.1 \mathrm{~m}$ and in $0.1-0.2 \mathrm{~m}$ showed different responses to water management techniques. In the top $0.1 \mathrm{~m}$, the root length per plant in M-P was the highest compared to the other three treatments in both growing seasons $(p<0.05)$. The root length in F-P was also higher than that in $\mathrm{F}-0$ and $\mathrm{M}-0$ in both growing seasons $(p<0.05)$. In contrast, the roots in $0.1-0.2 \mathrm{~m}$ were longer in $\mathrm{F}-0$ and $\mathrm{M}-0$, compared to F-P and M-P in both growing seasons $(p<0.05)$. In spring season, the total root length was higher in M-P than in F-0 $(p<0.05)$. The total root length was higher in M-P and F-P than in F-0 and M-0 in autumn season $(p<0.05)$. In both growing seasons, M-0, F-P, and M-P treatments increased the leaf area per plant and SPAD value compared to F-0, and the leaf area and SPAD value were higher in M-P and F-P than in M-0 $(p<0.05)$ (Table 2).

Table 2. Pakchoi morphology, including root length of root system in 0-0.1 $\mathrm{m}$ and $0.1-0.2 \mathrm{~m}$ and leaf area and SPAD value under different water management techniques in spring and autumn seasons.

\begin{tabular}{|c|c|c|c|c|c|c|}
\hline \multirow[t]{2}{*}{$\begin{array}{l}\text { Growing } \\
\text { Season }\end{array}$} & \multirow[t]{2}{*}{ Treatment } & \multicolumn{3}{|c|}{ Root Length (cm Plant ${ }^{-1}$ ) } & \multirow[t]{2}{*}{$\begin{array}{c}\text { Leaf Area } \\
\left(\mathrm{cm}^{2} \text { Plant }^{-1}\right)\end{array}$} & \multirow[t]{2}{*}{ SPAD Value ${ }^{1}$} \\
\hline & & 0-0.1 m & $0.1-0.2 \mathrm{~m}$ & Sum & & \\
\hline \multirow{4}{*}{ Spring } & F-0 & $652.27 c$ & $631.88 \mathrm{a}$ & $1284.15 b$ & $844.39 \mathrm{~d}$ & $37.90 \mathrm{~d}$ \\
\hline & M-0 & $751.25 \mathrm{c}$ & $568.64 \mathrm{~b}$ & $1319.89 \mathrm{~b}$ & 909.37 c & $39.23 c$ \\
\hline & F-P & $954.62 \mathrm{~b}$ & $359.50 \mathrm{c}$ & $1314.12 \mathrm{~b}$ & $1301.88 \mathrm{~b}$ & $40.20 \mathrm{~b}$ \\
\hline & M-P & $1119.61 \mathrm{a}$ & $388.79 c$ & $1508.4 \mathrm{a}$ & $1314.97 \mathrm{a}$ & $42.61 \mathrm{a}$ \\
\hline \multirow{4}{*}{ Autumn } & $\mathrm{F}-0$ & 705.82 c & 707.38 a & 1413.2 c & $734.83 \mathrm{~d}$ & $38.81 \mathrm{~d}$ \\
\hline & M-0 & 794.02 c & $647.24 \mathrm{a}$ & $1441.26 \mathrm{c}$ & $816.27 \mathrm{c}$ & $39.46 \mathrm{c}$ \\
\hline & F-P & $1309.56 \mathrm{~b}$ & $495.00 \mathrm{~b}$ & $1804.56 \mathrm{~b}$ & $1156.35 \mathrm{~b}$ & $42.61 \mathrm{~b}$ \\
\hline & M-P & $1462.40 \mathrm{a}$ & $460.81 \mathrm{~b}$ & $1923.21 \mathrm{a}$ & $1264.69 \mathrm{a}$ & $43.76 \mathrm{a}$ \\
\hline
\end{tabular}

Notes: F-0, M-0, F-P, and M-P were abbreviations for furrow irrigation, micro-irrigation, furrow irrigation with plastic mulch, and micro-irrigation with plastic mulch. The different lower-case letters indicate the significant difference among water management techniques in each season at $p<0.05(n=3) .{ }^{1}$ Arbitrary unit of SPAD-502 meter.

\subsection{Quality, Nutrient Concentration in Plants and Soil EC Values}

The vitamin $C$ and soluble sugar contents were influenced by water management techniques. The vitamin $\mathrm{C}$ contents was higher in M-P and F-P than in F-0 and M-0 in both growing seasons $(p<0.05)$. M-P increased the vitamin C content by $64 \%$ in spring season and $62 \%$ in autumn season, compared to F-0. F-P increased the vitamin C content by $53 \%$ in spring season and $46 \%$ in autumn season, related to F- 0 . The soluble sugar content in M-P was the highest among the four treatments in both growing seasons, and it was higher in F-P than in F-0 and M-0 in spring season $(p<0.05)$. Compared to F-0, M-P increased soluble sugar content by $49 \%$ in spring season and $60 \%$ in autumn 
season. F-P increased soluble sugar content by $35 \%$ in spring season and $54 \%$ in autumn season, related to F-0. On the contrary, the total content of cellulose, hemicellulose, and lignin was higher in F-0 and M-0 than in F-P and M-P in both growing seasons $(p<0.05)$. However, there was no difference in the content of hemicellulose among treatments in both growing seasons (Table 3).

Table 3. The Vitamin C, soluble sugar and cellulose, hemicellulose, and lignin contents in pakchoi under different water management techniques in spring and autumn seasons.

\begin{tabular}{|c|c|c|c|c|c|}
\hline \multirow[t]{2}{*}{$\begin{array}{c}\text { Growing } \\
\text { Seasons }\end{array}$} & \multirow[t]{2}{*}{ Treatment } & Vitamin C & Soluble Sugar 1 & $\begin{array}{c}\text { Cellulose, } \\
\text { Hemicellulose } \\
\text { and Lignin }^{2}\end{array}$ & Hemicellulose ${ }^{2}$ \\
\hline & & $\left(\mathrm{mg} 100 \mathrm{~g}^{-1}\right)$ & & $(\%)$ & \\
\hline \multirow{4}{*}{ Spring } & F-0 & $5.163 b$ & $2.41 \mathrm{~b}$ & $21.91 \mathrm{a}$ & $4.75 \mathrm{a}$ \\
\hline & M-0 & $6.256 \mathrm{~b}$ & $2.79 \mathrm{~b}$ & $20.31 \mathrm{a}$ & $3.43 \mathrm{ab}$ \\
\hline & F-P & $7.897 \mathrm{a}$ & $3.26 \mathrm{a}$ & $18.78 \mathrm{ab}$ & $4.05 \mathrm{a}$ \\
\hline & M-P & $8.444 \mathrm{a}$ & $3.58 \mathrm{a}$ & 17.02 b & $2.9 \mathrm{~b}$ \\
\hline \multirow{4}{*}{ Autumn } & $\mathrm{F}-0$ & $3.522 \mathrm{~b}$ & $2.52 \mathrm{~b}$ & $20.88 \mathrm{a}$ & $5.63 \mathrm{a}$ \\
\hline & M-0 & $4.616 \mathrm{~b}$ & $2.86 \mathrm{~b}$ & $20.12 \mathrm{a}$ & $5.14 \mathrm{a}$ \\
\hline & F-P & $5.163 \mathrm{a}$ & $3.88 \mathrm{ab}$ & $17.79 \mathrm{~b}$ & $4.96 \mathrm{a}$ \\
\hline & M-P & $5.709 \mathrm{a}$ & $4.02 \mathrm{a}$ & $17.01 \mathrm{~b}$ & $4.5 \mathrm{a}$ \\
\hline
\end{tabular}

Notes: F-0, M-0, F-P, and M-P were abbreviations for furrow irrigation, micro-irrigation, furrow irrigation with plastic mulch, and micro-irrigation with plastic mulch. The different lower-case letters indicate the significant difference among water management techniques in each season at $p<0.05(n=4) .{ }^{1}$ Soluble sugar content was expressed as percentage of pakchoi fresh weight. ${ }^{2}$ Cellulose, hemicellulose, and lignin contents were expressed as percentage of pakchoi dry weight.

In both growing seasons, the $\mathrm{N}$ and $\mathrm{P}$ content in both aboveground and belowground biomass was higher in M-P than in F-0, except for the $\mathrm{N}$ content in belowground biomass in autumn season $(p<0.05)$. The $\mathrm{N}$ and $\mathrm{P}$ content in aboveground biomass in F-P was higher than that in F-0 in both growing seasons, while the $\mathrm{N}$ and $\mathrm{P}$ content in belowground biomass was only higher in F-P than in F-0 in spring season $(p<0.05)$ (Figure 2). 

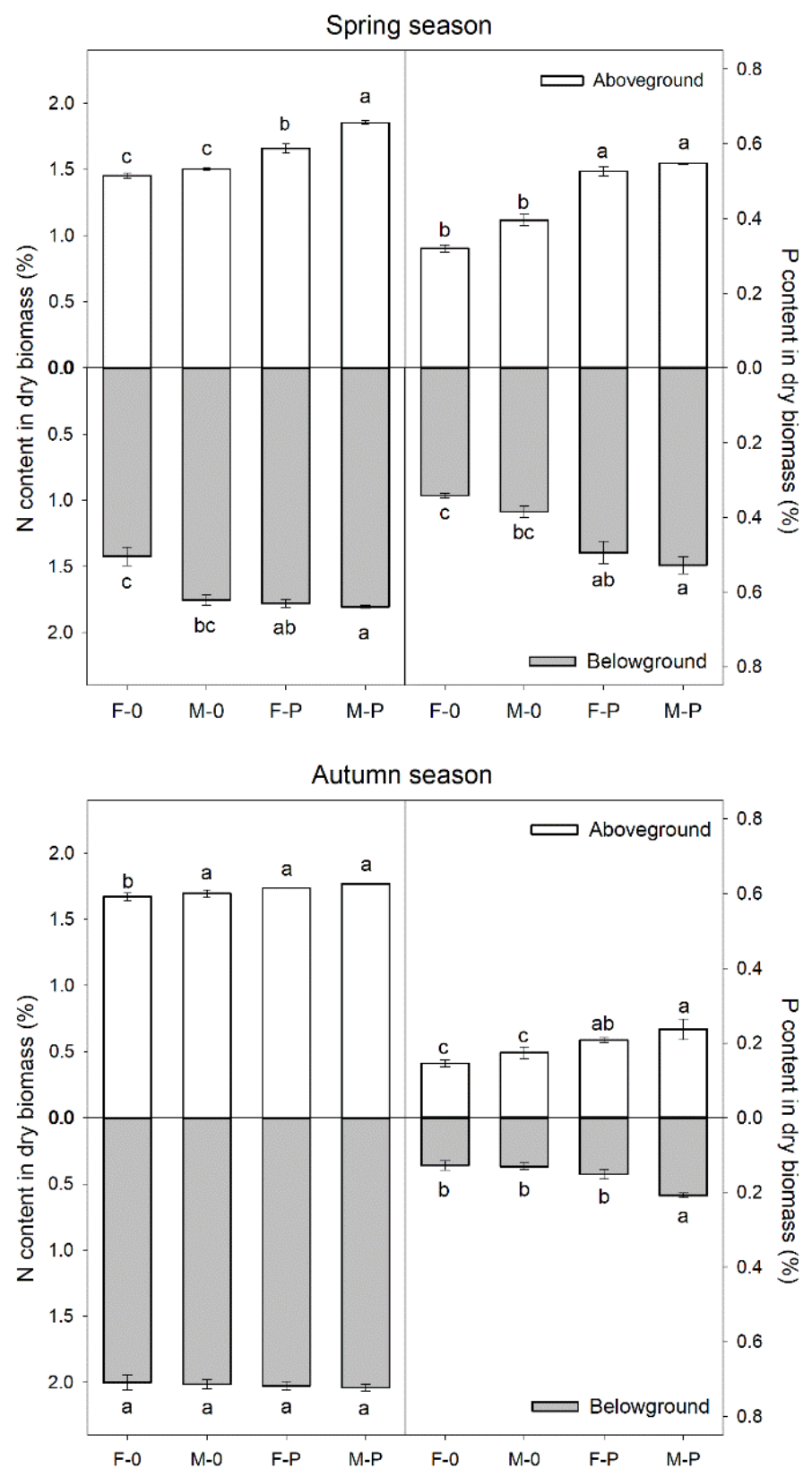

Figure 2. The $\mathrm{N}$ and $\mathrm{P}$ contents of aboveground and belowground pakchoi under water management techniques in spring and autumn seasons. F-0, M-0, F-P, and M-P were abbreviations for furrow irrigation, micro-irrigation, furrow irrigation with plastic mulch, and micro-irrigation with plastic mulch. The different lower-case letters indicate the significant difference among water management techniques in each season at $p<0.05(n=3)$.

There was no difference in soil EC values among treatments before sowing in two growing seasons. However, after harvesting, both F-P and M-P treatments showed lower EC values compared to F-0 and M-0 treatments in two growing seasons $(p<0.05)$ (Table 4$)$. 
Table 4. The EC values $\left(\mu \mathrm{S} \mathrm{cm}{ }^{-1}\right)$ in soil before sowing and after harvesting in top soil layers $(0-0.1$, $0.1-0.2$, and $0.2-0.3 \mathrm{~m}$ ) under different water management techniques in spring and autumn seasons.

\begin{tabular}{|c|c|c|c|c|c|}
\hline \multirow{2}{*}{ Soil Layer } & \multirow{2}{*}{ Treatment } & \multicolumn{2}{|c|}{ Spring } & \multicolumn{2}{|c|}{ Autumn } \\
\hline & & Before Sowing & $\begin{array}{c}\text { After } \\
\text { Harvesting }\end{array}$ & Before Sowing & $\begin{array}{c}\text { After } \\
\text { Harvesting }\end{array}$ \\
\hline \multirow{4}{*}{$0-0.1 \mathrm{~m}$} & $\mathrm{~F}-0$ & $1185.33 \mathrm{a}$ & $421.67 \mathrm{a}$ & $655.33 \mathrm{a}$ & $407.00 \mathrm{a}$ \\
\hline & M-0 & $1143.33 \mathrm{a}$ & $457.33 \mathrm{a}$ & $646.67 \mathrm{a}$ & $350.33 b$ \\
\hline & F-P & $1036.67 \mathrm{a}$ & $362.00 \mathrm{~b}$ & $603.00 \mathrm{a}$ & $272.67 \mathrm{c}$ \\
\hline & M-P & $1095.33 \mathrm{a}$ & $301.33 \mathrm{c}$ & $624.00 \mathrm{a}$ & $268.67 \mathrm{c}$ \\
\hline \multirow{4}{*}{$0.1-0.2 \mathrm{~m}$} & $\mathrm{~F}-0$ & $743.00 \mathrm{a}$ & $284.67 \mathrm{a}$ & $530.67 \mathrm{a}$ & $314.67 \mathrm{a}$ \\
\hline & M-0 & 730.33 a & $252.67 \mathrm{~b}$ & 517.33 a & 298.00 a \\
\hline & F-P & $760.33 a$ & $254.00 \mathrm{~b}$ & $521.33 \mathrm{a}$ & $287.67 \mathrm{~b}$ \\
\hline & M-P & $717.67 \mathrm{a}$ & $233.33 \mathrm{~b}$ & $496.00 \mathrm{a}$ & $256.33 b$ \\
\hline \multirow{4}{*}{$0.2-0.3 \mathrm{~m}$} & $\mathrm{~F}-0$ & $421.00 \mathrm{a}$ & $263.67 \mathrm{a}$ & $372.67 \mathrm{a}$ & $286.00 \mathrm{a}$ \\
\hline & M-0 & 457.33 a & $254.00 \mathrm{a}$ & $368.67 \mathrm{a}$ & 269.33 a \\
\hline & F-P & 437.33 a & $229.67 \mathrm{~b}$ & 349.67 a & $216.67 \mathrm{~b}$ \\
\hline & M-P & $446.67 \mathrm{a}$ & $208.33 c$ & $358.33 \mathrm{a}$ & $198.33 \mathrm{~b}$ \\
\hline
\end{tabular}

Notes: F-0, M-0, F-P, and M-P were abbreviations for furrow irrigation, micro-irrigation, furrow irrigation with plastic mulch, and micro-irrigation with plastic mulch. The different lower-case letters indicate the significant difference among water management techniques in each season at $p<0.05(n=4)$.

\subsection{Evapotranspiration and IWUE}

Irrigation was given twelve, eleven, ten, and nine times in F-0, M-0, F-P, and M-P, respectively, during the spring season. With extra irrigation given at sowing, the water consumption in spring season was reduced by 23,16 , and $9 \%$ in M-P $\left(2261 \mathrm{~m}^{3} \mathrm{ha}^{-1}\right)$, F-P $\left(2495 \mathrm{~m}^{3} \mathrm{ha}^{-1}\right)$, and M-0 $\left(2728 \mathrm{~m}^{3} \mathrm{ha}^{-1}\right)$, respectively, related to F-0 $\left(2962 \mathrm{~m}^{3} \mathrm{ha}^{-1}\right)$. In autumn season, irrigation was given nine, eight, seven, and six times in F-0, M-0, F-P, and M-P, respectively. Compared to the water consumption in F-0 in autumn season $\left(2190 \mathrm{~m}^{3} \mathrm{ha}^{-1}\right)$, the water was saved in M-P $\left(1533 \mathrm{~m}^{3} \mathrm{ha}^{-1}\right)$, F-P $\left(1752 \mathrm{~m}^{3} \mathrm{ha}^{-1}\right)$, and M-0 $\left(1971 \mathrm{~m}^{3} \mathrm{ha}^{-1}\right)$ treatments by 30,20 , and $10 \%$, respectively. The sum of evaporation amount was the highest in F-0, followed by M-0, F-P, and M-P $(p<0.05)$, regardless of growing seasons (Figure $3 \mathrm{~A})$. Transpiration was higher in M-P and F-P than in F-0 $(p<0.05)$ in spring, and transpiration in F-P was higher than in M-0 in autumn $(p<0.05)$ (Figure 3B). Additionally, the plant water content was higher in M-P and F-P in both growing seasons $(p<0.05)$ (Figure 3C). In both seasons, IWUE of pakchoi in $\mathrm{M}-\mathrm{P}$ was the highest among water management techniques and was improved by $84 \%$ in spring season and $95 \%$ in autumn season, compared to F-0. Besides, IWUE was higher in F-P than in F-0 and M-0 $(p<0.05)$, improved by $50 \%$ in both growing seasons (Table 1 ). 


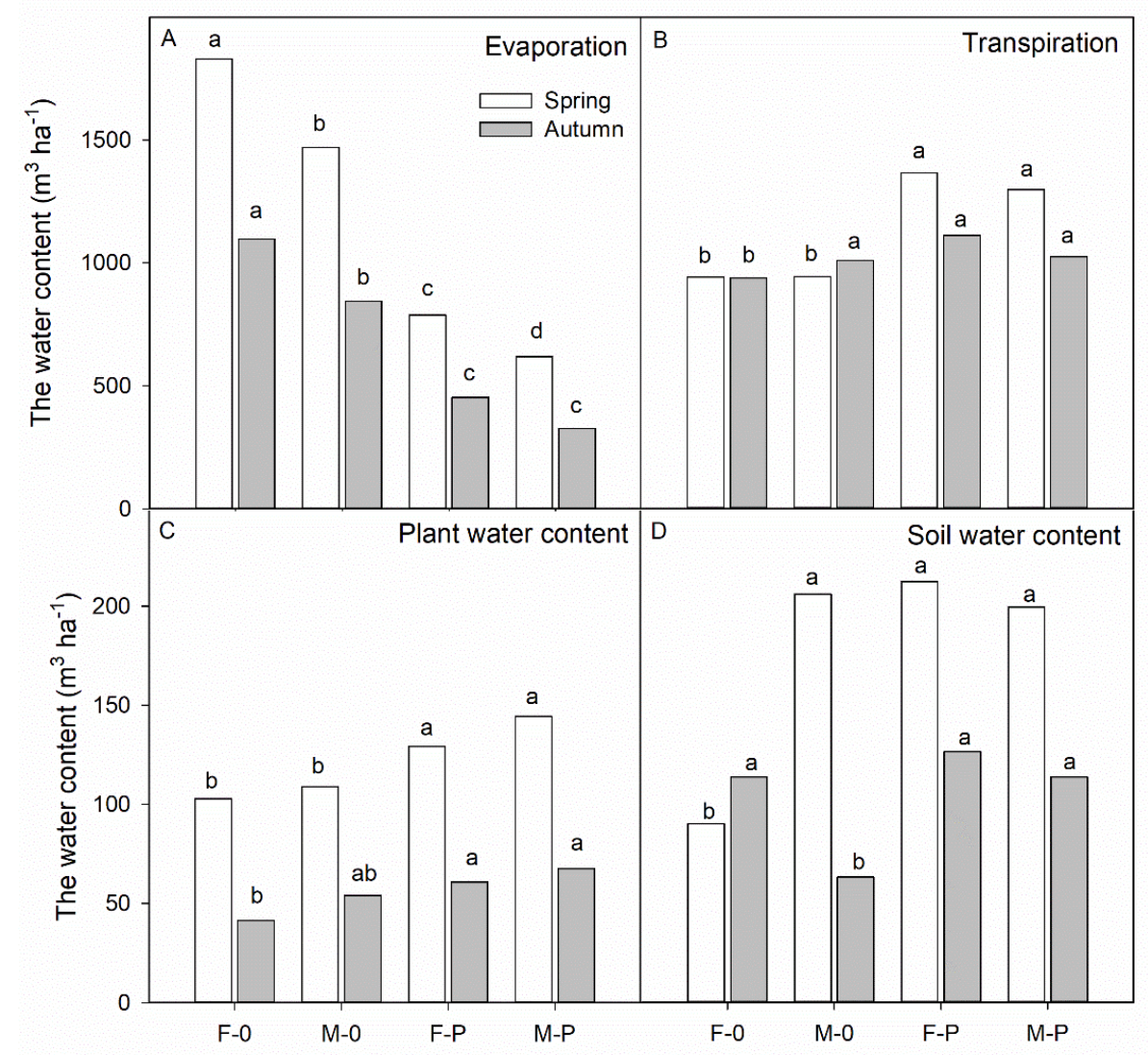

Figure 3. The irrigation water distribution under different water management techniques in spring and autumn seasons. (A): the sum of evaporation amount during the two growing seasons; (B): the sum of transpiration during the two growing seasons; (C): the plant water content at harvest; (D): the soil water content at harvest time. F-0, M-0, F-P, and M-P were abbreviations for furrow irrigation, micro-irrigation, furrow irrigation with plastic mulch, and micro-irrigation with plastic mulch. The different lower-case letters indicate the significant difference among water management techniques in each season at $p<0.05$ $(n=3)$.

\section{Discussion}

\subsection{Pakchoi Growth Stimulated by Water-Saving Techniques}

The two water-saving techniques with use of plastic mulch (M-P and F-P) stimulated the growth of pakchoi, confirming the first part of hypothesis 1 . However, the M-0 treatment did not show constant effect on pakchoi growth in the two growing seasons. The pakchoi yield in the present study was similar to the yield of $60 \mathrm{Mg} \mathrm{ha}^{-1}$ reported in a study where the plant density was only one-fifth of ours [24]. Compared to that study, the present study reported higher plant density but similar yield, indicating the intraspecific competition. Compared to the pakchoi in the F-0 treatment, the higher yield in the M-P treatment (spring and autumn seasons) and F-P treatment (only autumn) was the result of higher dry biomass accumulation (Table 1) and water content (Figure 3C). However, the influence of white plastic mulch on yield was inconsistent among other crops that were also planted with white plastic mulch. The inconsistent influence was probably due to the different agronomic conditions [25]. The stimulation of dry biomass accumulation under the M-P and F-P treatments in both growing seasons and under the $\mathrm{M}-0$ treatment in autumn season could be ascribed to the improved photosynthesis, indicated by increased total transpiration (Figure 3B) and leaf area and higher SPAD value (Table 2). The former two parameters are related to the extent of stomata openings beneficial to $\mathrm{CO}_{2}$ uptake and photosynthate synthesis [26], and the latter one reflected the total chlorophyll content and photosynthesis process [27]. The stimulated growth might also be a result 
of the increased soil temperature [10] or more stabilized daily range of soil temperature [28] caused by the plastic mulch used in the M-P and F-P treatments. Increased yields of crops such as lettuce (Lactuca sativa L.) and potato (Solanum tuberosum L.) have also been linked to increased soil temperature by plastic mulch, especially when the soil temperature was kept within an optimal range [10,29]. The underlying mechanism could be increased soil temperature enhancing root distribution in the top soil, subsequently improving nutrient uptake [30,31], as proved by $\mathrm{N}$ and $\mathrm{P}$ contents (Table 2, Figure 2) and decreased EC value (Table 4) in the present study. Moreover, the growth of pakchoi on mulched soil might be due to the high level of $\mathrm{CO}_{2}$ escaping from punched holes created by the trapping effect of the mulch [32]. The varying responses of dry biomass allocation aboveground and belowground to the three water-saving techniques might be attributed to the different cultivars and climatic conditions in the two growing seasons playing important roles in dry biomass allocation [13,33].

\subsection{Change of Root Morphology under Plastic Mulch}

Similar to pakchoi growth, root morphology was mainly influenced by the water-saving techniques with use of plastic mulch. The changed root morphology was probably a complex result of the changed micro-environment, such as temperature and gas exchange. In the present study, the total root length per pakchoi was in the range reported by Pant et al. [34]. Although the root dry biomass accumulation had different responses to the water-saving techniques in the two growing seasons, the root length exhibited similar responses to the techniques. Water is one factor that stimulates root plasticity and changes the root growth of crops [35]. However, neither severe water deficiency nor water infiltration in the soil layer deeper than $0.3 \mathrm{~m}$ was assumed in all treatments, since soil water content was kept in the range of $60-80 \%$ of field capacity in our case. The increased root length in the top part $(0-0.1 \mathrm{~m})$ under the M-P and F-P treatments could be ascribed to the increased soil temperature under plastic mulch, which has also been reported for maize (Zea mays L.), lettuce, and rape (Brassica napus subsp. napus) $[10,36,37]$. Additionally, plastic mulch might alter other factors, such as soil structure and nutrient cycling in the soil and consequently be beneficial to plant growth [38]. On the other hand, the increased root length in the upper part of the root system under plastic mulch (M-P and F-P) indicates that most of photosynthates were allocated to the upper part of the root system, resulting in a small portion of photosynthates in the lower part. The allocation pattern of photosynthates could explain the decreased root length in the lower part $(0.1-0.2 \mathrm{~m})$ of the root system. The change in root morphology might also be explained by the soil water distribution in soil layers: reduced evaporation from the top soil layer $(0-0.1 \mathrm{~m})$ ensured higher soil water content and allowed greater root development in terms of increased root length in the upper part $(0-0.1 \mathrm{~m})$, while less frequent changes in soil water content at $0.15 \mathrm{~m}$ (where the tensiometer was installed) did not stimulate root propagation in the lower part (0.1-0.2 m). Compared to most in-situ studies reporting the root distribution or root morphology with a $0.3 \mathrm{~m}$ interval in the soil profile, our study investigated the changes in root morphology with a $0.1 \mathrm{~m}$ interval in the top soil, where water and nutrient uptake primarily happen. A detailed investigation of root morphology is quite important for crops whose roots are mainly restricted to the top soil (i.e., $0-0.15 \mathrm{~m}$ ) by high soil nutrient contents in Chinese protected vegetable production [39].

\subsection{Quality of Pakchoi Improved by Water-Saving Techniques}

The two techniques with plastic mulch primarily improved the quality of pakchoi (Table 3), probably due to the improved micro-environment under the mulch and enhanced nutrient uptake, rather than the irrigation methods themselves. The results partly confirmed the first part of hypothesis 1. Many studies have linked such improvement with water stress [16,40], while large irrigation amount decreased the soluble solids content in tomatoes [41]. In the present study, the improved quality of pakchoi could not be ascribed to water stress, since the irrigation kept the field capacity in range of $60-80 \%$. On the other hand, we speculated that the improved quality (such as vitamin C and soluble sugar) was due to better uptake of nutrients such as $\mathrm{N}$ and $\mathrm{P}$, which are related to quality indices 
(soluble solids, titratable acidity, etc.) [42,43]. The cellulose, hemicellulose, lignin, and pectin are polysaccharides for constituting cell wall. Cellulose and hemicellulose biosynthesis are related to abiotic stress [44]. The decreased contents of cellulose, hemicellulose, and lignin under the F-P and M-P treatments implies that the environment in the two treatments was more suitable for pakchoi growth.

\subsection{Irrigation Water Use Improved by Water-Saving Techniques}

The water-saving techniques with plastic mulch improved the IWUE of pakchoi, confirming hypothesis 2. The improvement was mainly due to less irrigation water, reduced evaporation, and improved yield. The improvement in IWUE in F-P (50\% in both seasons) and M-P ( $84 \%$ in spring and $95 \%$ in autumn) treatments in two growing seasons was comparable to that in other studies on lettuce and maize $[10,11]$. Since the irrigation scheduling was based on water soil content, reducing inefficient water use was the primary approach to reduce water consumption. Evaporation under plastic mulch, accounting for $32-37 \%$ (spring) and $24-29 \%$ (autumn) of evapotranspiration, was reduced by more than half of that in the F-0 treatment (Figure 3A). Evaporation can be reduced by $74 \%$ with use of plastic mulch for watermelon (Citrullus lanatus) production in semiarid areas in China [12]. However, evaporation in the M-0 treatment, accounting for $61 \%$ (spring) and $46 \%$ (autumn) of evapotranspiration, was only reduced by $20 \%$ in spring and $23 \%$ in autumn related to that in furrow irrigation (F-0). Consequently, plastic mulch (F-P and M-P) (16-24\% in spring and $20-30 \%$ in autumn) showed better performance in water saving than $\mathrm{M}-0$ did ( $8 \%$ in spring and $10 \%$ in autumn), when compared to furrow irrigation (F-0), due to slow decrease in soil water content and reduced irrigation frequency. The proportion of water saving by using plastic mulch in the present study was comparable to that for cucumber (Cucumis sativus L.) production [30]. The varying effects on water saving between $\mathrm{M}-0$ and treatments with plastic mulch indicate that evaporation was the limiting factor when irrigation was scheduled based on soil water content. Along with soil evaporation, soil water storage could also be considered as an inefficient water use (i.e., $199 \mathrm{~m}^{3} \mathrm{ha}^{-1}$ for M-P in spring; Figure 3D). Soil water storage could be reduced, for instance by suppressing or decreasing the last irrigation event. This would have increased IWUE even further. On the other hand, the improved growing environment induced by plastic mulch enhanced the development of the root system and stimulated vegetative growth (Tables 1 and 2). It consequently enhanced the water and nutrient uptake and photosynthesis, resulting in 26-40\% (spring) and 45-63\% (autumn) increased yield of pakchoi in the two growing seasons regardless of irrigation method. The improved yield and reduced evaporation contributed to the high IWUE under plastic mulch. Water saving and yield improvement by using plastic mulch have also been reported for other crops $[10,11,30]$.

\section{Conclusions}

The use of plastic mulch combined with furrow irrigation and micro-irrigation enhanced the aboveground growth of pakchoi and primarily increased the root length in the top part of the root system $(0-0.1 \mathrm{~m})$ and consequently the total root length. The improved growth was probably a result of enhanced photosynthesis and nutrient uptake. The positive effect of plastic mulch on pakchoi further induced an improvement of quality compared to furrow irrigation without plastic mulch. The two water-saving techniques with use of plastic mulch showed better performance in reducing evaporation by $57-70 \%$ and the proportion of evaporation in evapotranspiration, and there was a more pronounced effect on reducing water consumption, which was more than double that in micro-irrigation without plastic mulch. The better performance of the two techniques with the use of plastic mulch indicates that evaporation was the limiting factor on water saving when irrigation was scheduled based on soil water content. The reduced water consumption and enhanced pakchoi growth consequently led to improved IWUE under the two techniques with the use of plastic mulch. Therefore, a combined irrigation scheduling based on soil water content with the use of plastic mulch is a feasible way to improve IWUE in protected vegetable production by reducing water consumption and enhancing crop growth. 
Author Contributions: Y.X. prepared the original paper, edited the paper, and contributed to visualization. S.W., C.L., and M.S. performed the field trials. M.S., Y.W., and J.Y. contributed to data analysis. Q.W. designed and coordinated the experiment, reviewed the paper, and administrated projects. All authors have read and agreed to the published version of the manuscript.

Funding: The study was financially supported by Beijing Leafy Vegetables Innovation Team of Modern Agro-industry Technology Research System (BAIC07-2020) and The Construction of Beijing Science and Technology Innovation and Service Capacity in Top Subjects (CEFF-PXM2019_014207_000032).

Conflicts of Interest: No conflicts of interest have been declared by all authors.

\section{References}

1. Zhang, Z.H.; Ma, Z.H. The general situation of China's greenhouse vegetable industry and the development focus of the "13th five-year plan". Chin. Veg. 2017, 5, 1-5.

2. Zhang, Y.; Shen, Y.; Sun, H.; Gates, J.B. Evapotranspiration and its partitioning in an irrigated winter wheat field: A combined isotopic and micrometeorologic approach. J. Hydrol. 2011, 408, 203-211. [CrossRef]

3. Nikolaou, G.; Neocleous, D.; Katsoulas, N.; Kittas, C. Irrigation of Greenhouse Crops. Horticulturae 2019 , 5 , 7. [CrossRef]

4. Zhu, X.; Li, Y.; Li, M.; Pan, Y.; Shi, P. Agricultural irrigation in China. J. Soil Water Conserv. 2013, 68, 147A-154A. [CrossRef]

5. Liu, H.; Yang, H.; Zheng, J.; Jia, D.; Wang, J.; Li, Y.; Huang, G. Irrigation scheduling strategies based on soil matric potential on yield and fruit quality of mulched-drip irrigated chili pepper in Northwest China. Agric. Water Manag. 2012, 115, 232-241. [CrossRef]

6. Wang, J.; Huang, G.; Li, J.; Zheng, J.; Huang, Q.; Liu, H. Effect of soil moisture-based furrow irrigation scheduling on melon (Cucumis melo L.) yield and quality in an arid region of Northwest China. Agric. Water Manag. 2017, 179, 167-176. [CrossRef]

7. Grafton, R.Q.; Williams, J.; Perry, C.J.; Molle, F.; Ringler, C.; Steduto, P.; Udall, B.; Wheeler, S.A.; Wang, Y.; Garrick, D.; et al. The paradox of irrigation efficiency. Science 2018, 361, 748-750. [CrossRef]

8. Rajak, D.; Manjunatha, M.V.; Rajkumar, G.R.; Hebbara, M.; Minhas, P.S. Comparative effects of drip and furrow irrigation on the yield and water productivity of cotton (Gossypium hirsutum L.) in a saline and waterlogged vertisol. Agric. Water Manag. 2006, 83, 30-36. [CrossRef]

9. Li, J.; Xu, X.; Lin, G.; Wang, Y.; Liu, Y.; Zhang, M.; Zhou, J.; Wang, Z.; Zhang, Y. Micro-irrigation improves grain yield and resource use efficiency by co-locating the roots and $\mathrm{N}$-fertilizer distribution of winter wheat in the North China Plain. Sci. Total Environ. 2018, 643, 367-377. [CrossRef]

10. Chen, Z.; Han, Y.; Ning, K.; Luo, C.; Sheng, W.; Wang, S.; Fan, S.; Wang, Y.; Wang, Q. Assessing the performance of different irrigation systems on lettuce (Lactuca sativa L.) in the greenhouse. PLoS ONE 2019, 14, e209329. [CrossRef]

11. Zhang, L.; Meng, Y.; Li, S.; Yue, S. High-yield characteristics and root support of rain-fed maize under film mulching. Agron. J. 2020, 112, 2115-2131. [CrossRef]

12. Wang, Y.; Xie, Z.; Malhi, S.S.; Vera, C.L.; Zhang, Y.; Guo, Z. Effects of gravel-sand mulch, plastic mulch and ridge and furrow rainfall harvesting system combinations on water use efficiency, soil temperature and watermelon yield in a semi-arid Loess Plateau of northwestern China. Agric. Water Manag. 2011, 101, 88-92. [CrossRef]

13. Zhang, X.; Chen, S.; Sun, H.; Wang, Y.; Shao, L. Root size, distribution and soil water depletion as affected by cultivars and environmental factors. Field Crop Res. 2009, 114, 75-83. [CrossRef]

14. Wang, C.; Liu, W.; Li, Q.; Ma, D.; Lu, H.; Feng, W.; Xie, Y.; Zhu, Y.; Guo, T. Effects of different irrigation and nitrogen regimes on root growth and its correlation with above-ground plant parts in high-yielding wheat under field conditions. Field Crop Res. 2014, 165, 138-149. [CrossRef]

15. Ozbahce, A.; Tari, A.F. Effects of different emitter space and water stress on yield and quality of processing tomato under semi-arid climate conditions. Agric. Water Manag. 2010, 97, 1405-1410. [CrossRef]

16. Zhang, H.; Xiong, Y.; Huang, G.; Xu, X.; Huang, Q. Effects of water stress on processing tomatoes yield, quality and water use efficiency with plastic mulched drip irrigation in sandy soil of the Hetao Irrigation District. Agric. Water Manag. 2017, 179, 205-214. [CrossRef] 
17. Steinmetz, Z.; Wollmann, C.; Schaefer, M.; Buchmann, C.; David, J.; Tröger, J.; Muñoz, K.; Frör, O.; Schaumann, G.E. Plastic mulching in agriculture. Trading short-term agronomic benefits for long-term soil degradation? Sci. Total Environ. 2016, 550, 690-705. [CrossRef]

18. Pei, Y.; Zhang, B.; Bie, Z. Effects of different field water capacities on growth and photosynthesis of lettuce. Southwest China J. Agric. Sci. 2015, 28, 1042-1046.

19. Trachsel, S.; Kaeppler, S.M.; Brown, K.M.; Lynch, J.P. Shovelomics: High throughput phenotyping of maize (Zea mays L.) root architecture in the field. Plant Soil 2011, 341, 75-87. [CrossRef]

20. Shidan, B. Soil and Agricultural Chemistry Analysis; China Agriculture Press: Beijing, China, 2000.

21. Leyva, A.; Quintana, A.; Sánchez, M.; Rodríguez, E.N.; Cremata, J.; Sánchez, J.C. Rapid and sensitive anthrone-sulfuric acid assay in microplate format to quantify carbohydrate in biopharmaceutical products: Method development and validation. Biologicals 2008, 36, 134-141. [CrossRef]

22. Association of Official Analytical Chemists (AOAC). Vitamin C (Ascorbic Acid) in Vitamin Preparations and Juices: 2, 6-Dichloroindophenol Titrimetric Method; AOAC: Washington, DC, USA, 1984.

23. VDLUFA. Bestimmung von Leicht Löslichen (Pflanzenverfügbaren) Haupt- und Spurennährstoffen, Band I, Die Untersuchung von Böden, 4th ed.; VDLUFA: Darmstadt, Germany, 1991.

24. Da Silva, G.H. Biodegradable mulch of recycled paper reduces water consumption and crop coefficient of pak choi. Sci. Hortic. 2020, 267, 109315. [CrossRef]

25. Greer, L.; Dole, J.M. Aluminum foil, aluminium-painted, plastic, and degradable mulches increase yields and decrease insectvectored viral diseases of vegetables. HortTechnology 2003, 13, 276. [CrossRef]

26. Cornic, G. Drought stress inhibits photosynthesis by decreasing stomatal aperture-not by affecting ATP synthesis. Trends Plant Sci. 2000, 5, 187-188. [CrossRef]

27. Reis, A.R.; Favarin, J.L.; Malavolta, E.; Júnior, J.L.; Moraes, M.F. Photosynthesis, chlorophylls, and SPAD readings in coffee leaves in relation to nitrogen supply. Commun. Soil Sci. Plant Anal. 2009, 40, 1512-1528. [CrossRef]

28. Xing, Z.; Toner, P.; Chow, L.; Rees, H.W.; Li, S.; Meng, F. Effects of hay mulch on soil properties and potato tuber yield under irrigation and nonirrigation in New Brunswick, Canada. J. Irrig. Drain. Eng. 2012, 138, 703-714. [CrossRef]

29. Hou, X.; Wang, F.; Han, J.; Kang, S.; Feng, S. Duration of plastic mulch for potato growth under drip irrigation in an arid region of Northwest China. Agric. For. Meteorol. 2010, 150, 115-121. [CrossRef]

30. Yaghi, T.; Arslan, A.; Naoum, F. Cucumber (Cucumis sativus L.) water use efficiency (WUE) under plastic mulch and drip irrigation. Agric. Water Manag. 2013, 128, 149-157. [CrossRef]

31. Wien, H.C.; Minotti, P.L.; Grubinger, V.P. Polyethylene mulch stimulates early root growth and nutrient uptake of transplanted tomatoes. J. Am. Soc. Hortic. Sci. 1993, 118, 207. [CrossRef]

32. Lament, W.J. Plastic mulches for the production of vegetable crops. HortTechnology 1993, 3, 35. [CrossRef]

33. Xia, S.; Deng, R.; Zhang, Z.; Liu, C.; Shi, G. Variations in the accumulation and translocation of cadmium among pak choi cultivars as related to root morphology. Environ. Sci. Pollut. Res. 2016, 23, 9832-9842. [CrossRef]

34. Pant, A.P.; Radovich, T.J.K.; Hue, N.V.; Miyasaka, S.C. Pak choi (Brassica rapa, Chinensis Group) yield, phytonutrient content, and soil biological properties as affected by vermicompost-to-water ratio used for extraction. HortScience 2012, 47, 395. [CrossRef]

35. Zhang, X.; Zhang, X.Y.; Liu, X.; Shao, L.; Sun, H.; Chen, S. Incorporating root distribution factor to evaluate soil water status for winter wheat. Agric. Water Manag. 2015, 153, 32-41. [CrossRef]

36. Mackay, A.D.; Barber, S.A. Soil temperature effects on root growth and phosphorus uptake by corn. Soil Sci. Soc. Am. J. 1984, 48, 818-823. [CrossRef]

37. Cumbus, I.; Nye, P. Root zone temperature effects on growth and phosphate absorption in rape Brassica napus cv. Emerald. J. Exp. Bot. 1985, 36, 219-227. [CrossRef]

38. Fang, S.; Xie, B.; Liu, D.; Liu, J. Effects of mulching materials on nitrogen mineralization, nitrogen availability and poplar growth on degraded agricultural soil. New For. 2011, 41, 147-162. [CrossRef]

39. Liang, X.; Gao, Y.; Zhang, X.; Tian, Y.; Zhang, Z.; Gao, L. Effect of optimal daily fertigation on migration of water and salt in soil, root growth and fruit yield of cucumber (Cucumis sativus L.) in solar-greenhouse. PLoS ONE 2014, 9, e86975. [CrossRef]

40. Najla, S.; Sanoubar, R.; Murshed, R. Morphological and biochemical changes in two parsley varieties upon water stress. Physiol. Mol. Biol. Plants 2012, 18, 133-139. [CrossRef] 
41. Kuşçu, H.; Turhan, A.; Demir, A.O. The response of processing tomato to deficit irrigation at various phenological stages in a sub-humid environment. Agric. Water Manag. 2014, 133, 92-103. [CrossRef]

42. Wang, Y.T.; Huang, S.W.; Liu, R.L.; Jin, J.Y. Effects of nitrogen application on flavor compounds of cherry tomato fruits. J. Plant Nutr. Soil Sci. 2007, 170, 461-468. [CrossRef]

43. Yang, K.; Wang, F.; Shock, C.C.; Kang, S.; Huo, Z.; Song, N.; Ma, D. Potato performance as influenced by the proportion of wetted soil volume and nitrogen under drip irrigation with plastic mulch. Agric. Water Manag. 2017, 179, 260-270. [CrossRef]

44. Le Gall, H.; Philippe, F.; Domon, J.M.; Gillet, F.; Pelloux, J.; Rayon, C. Cell wall metabolism in response to abiotic stress. Plants 2015, 4, 112-166. [CrossRef] [PubMed]

(C) 2020 by the authors. Licensee MDPI, Basel, Switzerland. This article is an open access article distributed under the terms and conditions of the Creative Commons Attribution (CC BY) license (http://creativecommons.org/licenses/by/4.0/). 